\title{
THE CHRISTIAN MARTYR \\ AS A HYPERTHANATIC PHILOSOPHER AND MYSTES, AND THE SUCCESS OF CHRISTIANITY
}

Why did Christianity succeed? In the history of research on late antiquity various explanations have been advanced to account for Christianity's final triumph, for example Church organization, political crisis, the erosion of pagan culture, Christian humanitarianism, etc. ${ }^{1}$ There are many mutually non-exclusive responses and, as Rodney Stark has stated, "there is no single answer as to why Christianity succeeded; a whole series of factors were involved."

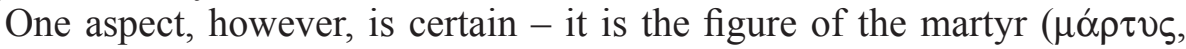
Greek for "witness"), the porte-parole of the victorious religion, which in the eyes of the ancient Christians assured Christianity's final success. Paradoxically, it is the blood of martyrs that was to multiply the ranks of the Christians: "Plures efficimur quotiens metimur a vobis: semen est sanguis Christianorum." ${ }^{3}$ To what extent did this belief, as expressed by Tertullian, correspond to the historical reality and to what extent did martyrs contribute to Christianity's final success? Scholars' opinions are divided. It seems reasonable, nevertheless, to admit that the figure of the martyr, which for over 150 years was so consistently promoted by the Christian movement, possessed certain objective features that exerted an effective influence on the pagan addressees of Christian martyrdom (testimony). ${ }^{4}$ Hence the conclusion that un-

* Jan M. Kozłowski Ph.D. - Assistant Professor, Institute of Classical Studies, Department of Polish Studies, University of Warsaw; e-mail: jan.kozlowski@uw.edu.pl.

${ }^{1}$ See such fundamental studies as E.R. Dodds, Pagan and Christian in an Age of Anxiety, Cambridge 1965; R.L. Fox, Pagans and Christians in the Mediterranean World from the Second Century AD to the Conversion of Constantine, San Francisco 1986; R. Stark, The Rise of Christianity. A Sociologist Reconsiders History, Princeton 1996.

${ }^{2}$ R. Stark, Reconstructing the rise of Christianity: The Role of Women, "Sociology of Religion" 56 (1995) 229.

${ }^{3}$ Tertullianus, Apologeticum 50, 13, ed. E. Dekkers, CCL 1, Turnhout 1954, 171.

${ }^{4}$ See first of all D. Karłowicz, The Archparadox of Death: Martyrdom As a Philosophical Category, Frankfurt am Main 2016; for primary sources on how Christian martyrdom affected its addressees, see Acta Carpi 42 (below); Martyrium Potamiaenae et Basilidis, ed. H. Musurillo, in: Acts of the Christian Martyrs, Oxford 1972, 132-135; Iustinus Martyr, Apologia secunda 12, 1-2 (see below); Martyrium Polycarpi 19, 1, ed. B. Dehandschutter, in: Polycarpiana. Studies on Martyrdom and Persecution in Early Christianity. Collected Essays, Bibliotheca Ephemeridum Theologicarum 
derstanding how the figure of the martyr was constructed can contribute to answering the general question of why Christianity finally succeeded.

In the present paper I would like to demonstrate that the figure of the martyr combined, among other aspects, two of ancient culture's most important answers to the problem of human mortality: (1) the figure of the mystes who, due to immediate and intimate contact with the divine, passes through death and is filled with hope of immortality; (2) the figure of the dying philosopher who by his steadfast attitude toward death shows that death has no more power over him. In such a construction of the figure of the martyr one can observe one more aspect of the ideological success of Christianity in late antiquity.

\section{Human mortality as the central problem in ancient anthropology.} For the ancient Greeks and Romans, human mortality was a basic anthropo-

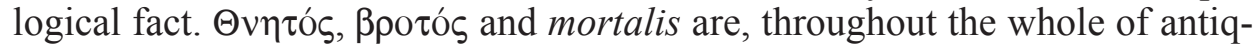
uity, synonyms of "man," defining his fragile nature in an exhaustive manner. At the same time, human mortality is accentuated by the main feature of

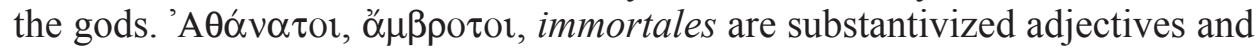
synonyms for $\theta \varepsilon o$ í and $d i$. This correlation was clearly expressed by Lucian of Samosata in the dialogue Vitarum auctio, in which we read: "Buyer: "What are men?» Heraclitus: «Mortal gods ( $\theta \varepsilon$ coi $\theta v \eta \tau o i ́) »$. Buyer: «And the gods?»

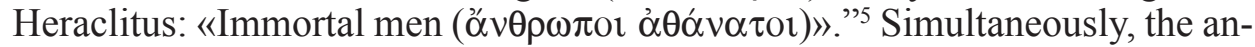
cients perceived death as the greatest evil, as death to them, citing Epicurus'

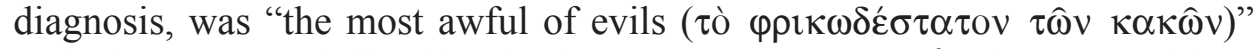

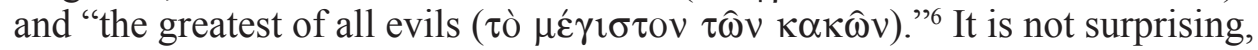
therefore, that the main soteriological postulate of the ancient world (using

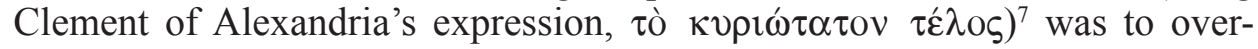
come human mortality. Among a range of propositions (for example having offspring, winning immortal fame, the gift of wine ${ }^{8}$ ), two ways of overcoming

Lovaniensium 205, Leuven 2007, 21, transl. É. Rebillard, in: Greek and Latin Narratives About the Ancient Martyrs, Oxford 2017, 103: "Such are the events concerning the blessed Polycarp. Though he was the twelfth counting those from Philadelphia to be martyred in Smyrna, he alone is remembered by all, so that he is talked about everywhere, even by the pagans ( $\tilde{\sigma \tau \varepsilon} \kappa \alpha i$ vं $\dot{\varepsilon} \theta \nu \hat{\omega} \nu \dot{\varepsilon} \nu \pi \alpha \nu \tau i ̀ ~ \tau o ́ \pi \omega ~ \lambda \alpha \lambda \varepsilon \hat{\imath} \sigma \theta \alpha \imath)$. He was not only a remarkable teacher, but also an outstanding

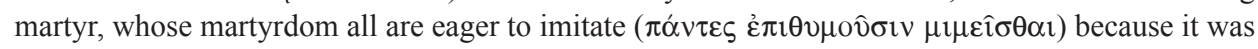
according to the gospel of Christ."

${ }^{5}$ Lucianus, Vitarum auctio 14, ed. M.D. Macleod: Luciani opera, vol. 2, Oxford 1974, 35-36, transl. A.M. Harmon: Lucian, vol. 2, LCL, Cambridge (Mass.) - London 1960, 477.

${ }^{6}$ Diogenes Laertius, Vitae philosophorum 10, 125, ed. T. Dorandi: Diogenes Laertius, Lives of Eminent Philosophers, New York 2013, 806-807, transl. R.D. Hicks: Diogenes Laertius, Lives of Eminent Philosophers, vol. 2, LCL, Cambridge (Mass.) - London 1958, 651.

${ }^{7}$ Clemens Alexandrinus, Protrepticus 113, ed. M. Marcovich: Clementis Alexandrini Protrepticus, Supplements to Vigiliae Christianae 34, Leiden - New York - Köln 1995, 163.

${ }^{8}$ As we read in Euripides' Bacchae about the gift of wine: "It delivers miserable mortals

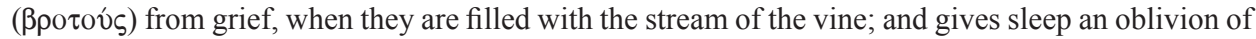
daily evils ( 
man's mortal condition had particular weight: (1) initiation into the mysteries, and (2) a philosophical attitude toward suffering and death.

\section{Initiation into the mystery cults as a way of overcoming human} mortality. For the ancient Greeks and Romans, the order of the world, i.e., that reality persists as cosmos and does not disintegrate into chaos, depended on the way people related to the gods. The core of ancient religion and the main task of men was to return to the gods what belonged to them in official worship ( $\theta \varepsilon \rho \alpha \pi \varepsilon i \alpha$ $\theta \varepsilon \hat{\omega} v$, cultus deorum). What mattered was the external, objective act of worship, while a personal relationship to divinity was beyond the scope of official religion whose soteriology and eschatology were confined to issues of this world.

For the ancient homo religiosus, for whom death was - evoking Epicurus' definition again - "the greatest of all evils," external $\theta \varepsilon \rho \alpha \pi \varepsilon i \alpha$ $\theta \varepsilon \hat{\omega} v$ could not suffice. Thus there existed parallel cults which allowed for an immediate and intimate connection with the divine and immortal. These were the mystery cults - Eleusinian Mysteries, Dionysian Mysteries, Mysteries of Isis and Osiris, Mysteries of Cybele and Attis, and Mysteries of Mitra, to name the most important. "Mystery cults represent the spiritual attempts of the ancient Greeks to deal with their mortality."

The mysteries were shrouded in secrecy. Those who has been initiated

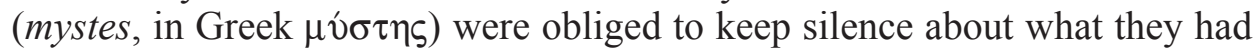
experienced. Our knowledge of them, despite many studies, is therefore still quite incomplete and largely conjectural. What we do know with certainty is that the aim of the mystery celebrations, which consisted, among other things, of processions, performances, play of light, ablutions, and ritual meals, was to make possible man's meeting with an immortal being - a meeting more intense and intimate than in the official cult: "Mysteries provide an immediate encounter with the divine." 10

The result of encountering the divine was for the mystes, besides other blessings relating to earthly life, to obtain hope that death would not be the end. And so, for example, in the Hymn to Demeter we read about those initiated into the Eleusinian mysteries, which were the oldest mysteries and paradigmatic of later mystery cults: "Blessed (ö $\lambda \beta 10 \varsigma$ ) is he of men on earth who has beheld them, | whereas he that is uninitiated in the rites, or he that has had no part in them,

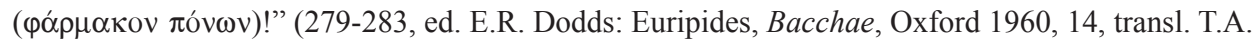
Buckley, The Tragedies of Euripides, vol. 1, New York 1877, 255), while in Diphilus' comedy

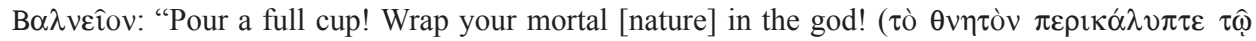
$\theta \varepsilon \hat{\omega})$ )" (frg. 20, ed. J.M. Edmonds, in: The Fragments of Attic Comedy, vol. 3a, Leiden 1961, 106, my translation).

${ }^{9}$ M.B. Cosmopoulos, Preface, in: Greek Mysteries. The Archaeology and Ritual of Ancient Greek Secret Cults, ed. M.B. Cosmopoulos, London - New York 2003, i.

${ }^{10}$ W. Burkert, Ancient Mystery Cults, Cambridge (Mass.) - London 1987, 90. 


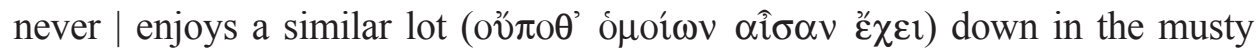
dark when he is dead." "' A few centuries later, Cicero wrote that the mysteries of Eleusis gave to humanity "the power not only to live happily, but also to die with a better hope (cum spe meliore moriendi)." 12 In Apuleius' Metamorphoses, the goddess Isis appears to Lucius and promises him that if he initiates into her mysteries he will honor her by "living himself in the Elysian fields (campos Elysios incolens ipse)." "13 "Once initiated, the individual was liberated from the fear of death by sharing the eternal truth, known only to the immortals." 14

How did the mystes gain immortality? Although do not know much about the mystery rites themselves, we do have hints that allow us to conjecture what could have been the correlation between the mystes's intimate experience of the divine and his gaining immortality. As one can easily observe, the fate of many of the gods worshiped in the mystery cults was closely connected with their death and resurrection. Persephone, Dionysus, Osiris and Attis are divinities who die and return to life. Since the death of a divinity and its subsequent return to life is not a frequent motif in ancient religion, a visible overrepresentation in the mystery cults of dying and resurrecting deities can provide a hint as to how to interpret the salvific dimension of initiation into the mysteries. The mystes entering into communion with the deity, became a participant in its fate. "The mystery gods' direct experience of death is fundamental to what they were subsequently able to achieve: life can triumph only because they have gained immortality. Death brings them close to human beings, while the rebirth they offer has a grandeur about it unattainable by the traditional gods of the Graeco-Roman pantheon." 15

${ }^{11}$ Hymnus in Cererem 480-482, ed. and transl. M.L. West, in: Homeric Hymns, Homeric Apocrypha, Lives of Homer, LCL, Cambridge (Mass.) - London 2003, 70-71.

${ }_{12}$ Cicero, De legibus 2, 36, ed. C. Büchner: M. Tulli Ciceronis De Legibus libri tres, Firenze 1973, 74, transl. C.W. Keyes, in: Cicero. De re publica, De legibus, vol. 16, LCL, Cambridge (Mass.) - London 1988, 415; Sophocles, frg. 837, ed. S. Radt, in: Tragicorum Graecorum fragmenta, vol.

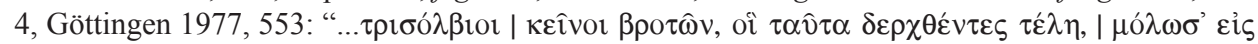

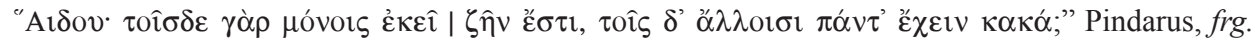

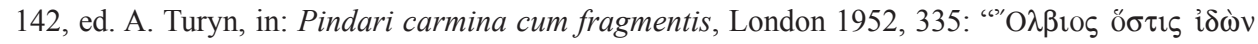

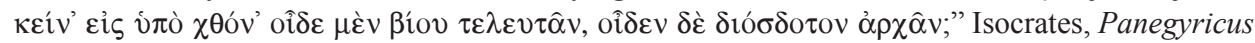
28, ed. É. Brémond - G. Mathieu: Isocrate, Discours, vol. 2, Les Belles Lettres, Paris 1956, 21:

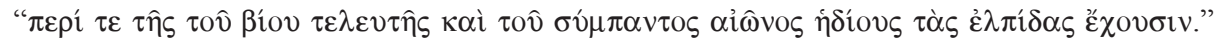

${ }^{13}$ Apuleius, Metamorphoses 11, 6, ed. R. Helm: Apuleius, Metamorphoseon libri XI, Berlin 2008, 271, my translation.

${ }^{14}$ Cosmopoulos, Preface, p. i; R. Reitzenstein, Die hellenistichen Mysterienreligionen nach ihren Grundgedanken und Wirkungen, Leipzig 19723, 9: "Um Untersterblichkeit [...] handelt es sich bei dem eigentlich religiösen Teil dieser Mysterien immer." A more balanced attitude to this issue was adopted by W. Burkert (Ancient Mystery Cults) and J. Bremmer (Initiation into the Mysteries of the Ancient World, Münchner Vorlesungen zu antiken Welten 1, Berlin - Boston 2014).

${ }^{15}$ J. Alvar, Romanising Oriental Gods. Myth, Salvation and Ethics in the Cults of Cybele, Isis and Mithras, Religions in the Graeco-Roman World 165, Leiden - Boston 2008, 34. 
3. Mors philosophi as a way of overcoming human mortality. GraecoRoman culture's second major way of breaking the power of death was philosophical reflection. In Plato's Phaedo, Socrates says: "The true philosophers practice dying, and death is less terrible to them than to any other men ( $\tau$ ò

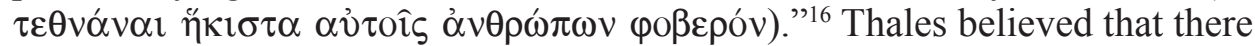

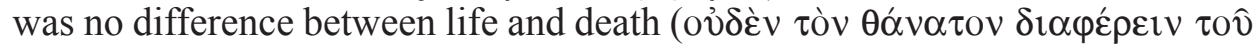
$\zeta \hat{\eta} v) .{ }^{17}$ When Anaxagoras was informed that he was condemned to death and that his sons were dead, his comment on the sentence was: "Long ago nature condemned both my judges and myself to death," and of his sons' deaths he said: "I knew that my children were born to die." 18 Finally, Epicurus stated: "Death $[\ldots]$ is nothing to us, seeing that, when we are, death is not come, and, when death is come, we are not." ${ }^{19}$ However, no matter how smart the theoretical considerations on the nature of death were, only the behavior of the philosopher in extremis could become real proof that death is something relative.

Anaxarchus of Abdera, Pyrrho's teacher seized by the tyrant Nicocreon, was put into a mortar and then pounded to death with iron pestles. Anaxarchus,

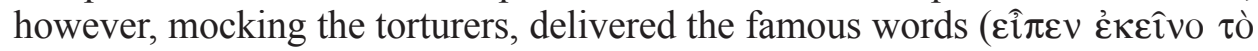
$\pi \varepsilon \rho \iota \varphi \varepsilon \rho o ́ \mu \varepsilon v o v)$ : "Pound, pound the pouch containing Anaxarchus; you do not

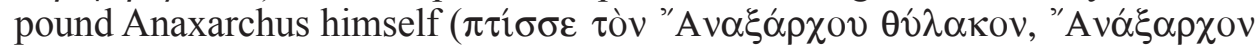

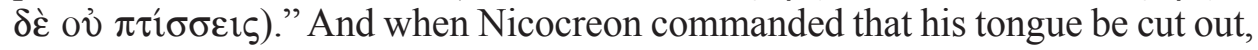
he bit it off and spat it at him. ${ }^{20}$ The gymnosophist Calanus, whom Alexander encountered during his Indian campaign, performed a fully controlled act of self-immolation in the presence of the Greeks. According to Plutarch: "Nor did he move as the fire approached him, but continued to lie in the same posture as at first, and so sacrificed himself acceptably." ${ }^{21}$ The way Calanus accepted death made a huge impression on the Greeks. Zeno of Citium, the founder of stoicism, stated "he would rather have seen one Indian roasted - than have learned the whole of arguments about bearing pain." ${ }^{22}$ Under the influence of Calanus's self-immolation, Pyrrho, the founder of skepticism, realized that even what is commonly considered the greatest suffering is in fact something relative, and that the philosopher can remain happy even during the greatest torment. ${ }^{23}$

${ }^{16}$ Plato, Phaedo 67e, ed. I. Burnet, in: Platonis opera, vol. 1, Oxford 1967 [no pagination], transl. H.N. Fowler, in: Plato, vol. 1: Eutyphro, Apology, Crito, Phaedo, Phaedrus, Cambridge (Mass.) - London 2005, 235.

${ }^{17}$ Diogenes Laertius, Vitae philosophorum 1, 35, ed. Dorandi, p. 87.

${ }^{18}$ Ibidem 2, 13, ed. Dorandi, p. 156-157, transl. Hicks, vol. 2, p. 143.

${ }^{19}$ Ibidem 10, 125, ed. Dorandi, p. 806, transl. Hicks, vol. 2, p. 651.

${ }^{20}$ Ibidem 9, 59, ed. Dorandi, p. 699, my translation.

${ }^{21}$ Plutarchus, Alexander 69, ed. C. Lindskog - K. Ziegler: Plutarchi vitae parallelae, vol. 2 , Leipzig 1968, 243; transl. B. Perrin: Plutarch's Lives, vol. 7, LCL, Cambridge (Mass.) - London 1967, 419.

${ }^{22}$ Clemens Alexandrinus, Stromata 2, 20, 125, ed. O. Stählin, GCS 15, Berlin 1985, 180, transl. B.P. Pratten, ANF 2, Grand Rapids 1983, 374.

${ }^{23}$ Cf. G. Reale, Storia della Filosofia Antica, vol. 3, Milano 1987, 470-471: “Calano, dunque, 
The steadfastness of the philosopher in the face of death, as proof that death is not the ultimate and absolute reality, was most clearly shown in Plato's Phae$d o$, in which the last moments of Socrates are described. The main philosophical topic of the Phaedo is the issue of the immortality of the soul. Plato, through the mouth of Socrates, provides arguments that the soul is immortal. The dialogue ends with the death of Socrates. When the philosopher takes the cup of hemlock, he does it "without trembling or changing color or expression.". Then we read that he drinks the poison "very cheerfully and quietly." ${ }^{25}$ When the others despair and pour their tears, Socrates' sense of humor does not leave him until the very end. It is not difficult to guess why Plato described Socrates' heroic death in the Phaedo, a dialogue devoted to the problem of the immortality of the soul (the Phaedo's subtitle is " $\pi \varepsilon \rho i$ is Socrates himself and his death that are final (one could say "metalogical") argument for the immortality of the soul. Through his $\alpha \tau \alpha \rho \alpha \xi i \alpha$, Socrates implicitly reveals that death has no power over the soul. The way Socrates accepted death echoed powerfully first in the Greek and then in the Graeco-Roman world. ${ }^{26}$ Already Aristippus, Socrates' disciple, when asked how Socrates died, answered: "As I would wish to die myself.", 27

To sum up, ancient culture's soteriological answer to the problem of human mortality focused on two figures: (1) that of the mystes who gains eternal life by identifying with the death and resurrection of a divinity, and (2) that of the dying philosopher who, in the presence of suffering and death, relativizes the power of death through his steadfast attitude.

4. The martyr as a hyperthanatic philosopher. The pagans acknowledged the extraordinary courage and endurance of the Christians in their suffering. The Roman rhetorician and advocate Marcus Cornelius Fronto of Cirta wrote of them:

"They despise present torments (spernunt tormenta praesentia), although they fear those which are uncertain and future; and while they fear to die after death, they do not fear to die for the present (mori non timent)." ${ }^{.28}$

dimostrava che, se è possibile accogliere con impassibilità anche quelli che sono considerati i peggiori dei mali, questi non debbono avere di per sé quella «realtà» e quella «natura» che vengono loro comunemente attribuite e che, in ogni caso, il saggio può essere in grado di porsi al di sopra di essi $[. .$.$] . Pirrone nella testimonianza di Calano vide la dimostrazione al vivo di quell'idea che,$ come abbiamo visto, era destinata a trionfare nell'età ellenistica, e cioè che il saggio può essere felice anche fra i tormenti."

${ }^{24}$ Plato, Phaedo 117b, ed. Burnet, transl. Fowler, p. 399.

${ }^{25}$ Ibidem 117c, ed. Burnet, transl. Fowler, p. 401.

${ }^{26}$ Cf. G. Sterling, Mors philosophi: The Death of Jesus in Luke, HTR 94 (2001) 387-390.

${ }^{27}$ Diogenes Laertius, Vitae philosophorum 2, 76, ed. Dorandi, p. 196, transl. Hicks, vol. 1, p. 205.

${ }^{28}$ Minucius Felix, Octavius 8, 5, ed. B. Kytzler: Octavius, München 1965, 68, transl. R.E. Wallis, ANF 4, Peabody (Mass.) 1995, 177. 
When writing about the philosopher's courageous acceptance of death, Marcus Aurelius makes the reservation: "This resolve, too, must arise from a spe-

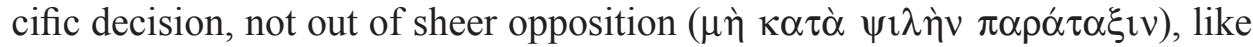
the Christians." ${ }^{29}$ The pagan scoffer Lucian of Samosata observed: "The poor wretches have convinced themselves, first and foremost, that they are go-

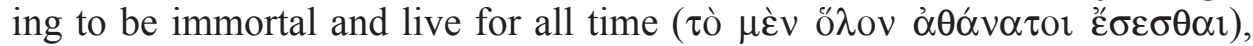

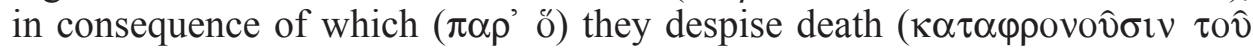

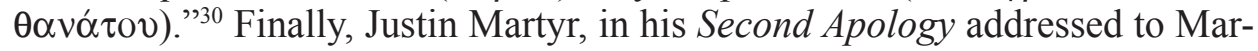
cus Aurelius, writes:

"For I myself, too, when I was delighting in the doctrines of Plato, and heard

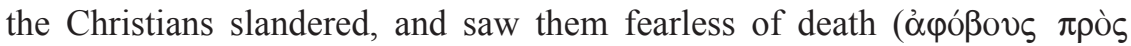
$\theta \alpha \dot{\alpha} \alpha \tau \circ v)$, and of all other things which are counted fearful, perceived that it was impossible that they could be living in wickedness and pleasure. For what sensual or intemperate man, or who that counts it good to feast on human flesh, could welcome death ( $\theta \alpha \dot{\alpha} \alpha \tau o v$ ó $\sigma \pi \alpha ́ \zeta \varepsilon \sigma \theta \alpha 1)$, that he might be deprived of his enjoyments?"31

This attitude of the Christians in the face of death became an essential element of the concept of the martyr. In the Ante-Nicene martyrological literature, all martyrs inherently share supernatural resistance to suffering and courage that allows them to go to death with their heads always held high. And so, for example, in Martyrium Lugdunensium we read that future martyrs

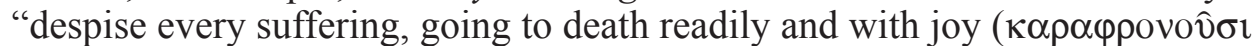

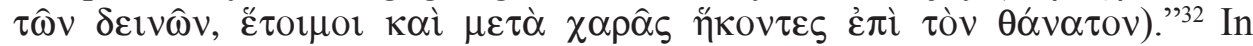

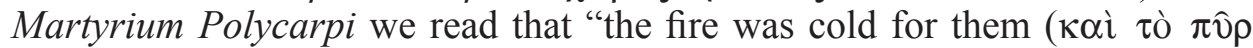

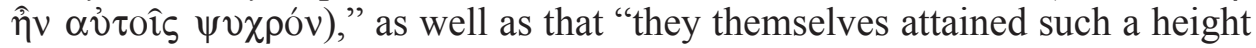

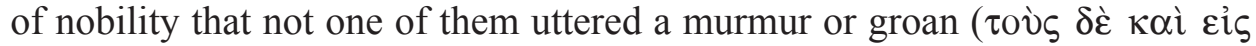

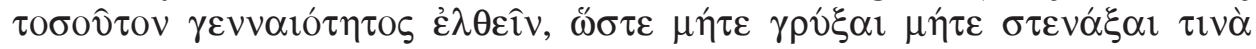
$\alpha \hat{\tau} \tau \hat{\omega} v) .{ }^{\prime 33}$ Similar examples could be quoted ad libitum.

The death of the martyr depicted in this manner clearly fits (at least in its external aspect) the ideal of the death of the philosopher, or, using Greg Sterling's expression, the ideal of mors philosophi. ${ }^{34}$ The Greek physician, surgeon and philosopher Galen states that the deeds of the Christians are "equal to the

${ }^{29}$ Marcus Aurelius, Meditationes 11, 3, ed. and transl. A.S.L. Farquharson: The Meditations of the Emperor Marcus Antoninus, Oxford 1944, 216-217.

${ }^{30}$ Lucianus, De morte Peregrini 13, ed. M.D. Macleod: Luciani opera, vol. 3, Oxford 1974, 192, transl. A.M. Harmon: Lucian, vol. 5, LCL, Cambridge (Mass.) - London 1962, 15.

${ }^{31}$ Iustinus Martyr, Apologia secunda 12, 1-2, ed. A. Wartelle, in: Saint Justin, Apologies, Études Augustiniennes, Paris 1987, 212, transl. A. Roberts - J. Donaldson, ANF 1, Grand Rapids 1981, 192.

${ }^{32}$ Martyrium Lugdunensium 1, 63, ed. A.P. Orbán: Martyrium Lugdunensium, in: Atti e Passioni dei Martiri, ed. A.A.R. Bastiaensen (et alii), Milano 1987, 90, transl. É. Rebillard, in: Greek and Latin Narratives, p. 169.

${ }^{33}$ Martyrium Polycarpi 2, 2-3, ed. Dehandschutter, p. 8, transl. Rebillard, p. 91.

${ }^{34}$ Cf. Sterling, Mors philosophi, p. 383-402. 
deeds of those who are in truth philosophers. For example, that they are free from the fear of death, is a fact which we all have observed." 35 In the words of Marcus Aurelius (quoted above), we can observe a certain irritation that the Christians, although they go to their death without the preparation and reflection proper to true philosophers, fulfill the ideal of mors philosophi. In his Diatribae,

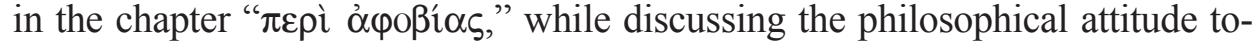
ward "external things," best expressed by the absence of fear in front of a tyrant and his thugs, Epictetus writes: "And is it possible that any one should be thus disposed toward these things from madness, and the Galileans from mere habit

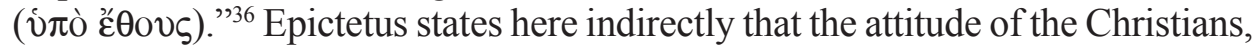
at least in its external aspect, fits the ideal of mors philosophi. "It is evident that Lucian, Marcus Aurelius, Galen and Celsus were all, despite themselves, impressed by the courage of the Christians in face of death and torture." ${ }^{37}$

That the Christians wanted the martyrs' attitude toward death to be interpreted as mors philosophi is witnessed by Martyrium Pionii, where just before his death Pionius says: "Socrates did not suffer in such a way from the Athenians. Now every man is an Anytus and a Meletus." ${ }^{38}$ When the executioners want to nail Polycarp to the stake, the Smyrnean bishop says: "Leave me thus, for he who allows me to endure the fire will also allow me, even without the security of the nails, to remain on the pyre without moving ( $\alpha \sigma \alpha ́ \lambda \varepsilon v \tau o v$ $\dot{\varepsilon} \pi \iota \mu \varepsilon \hat{\imath} v \alpha \imath \tau \hat{n} \pi v \rho \hat{\alpha}) .{ }^{\prime \prime 39}$ A contextual and intertextual analysis of these words shows that we are dealing with a reference to the motif of the Indian gymnosophist burning steadfastly on the pyre..$^{40}$ As we remember, Zeno of Citum said: "He would rather have seen one Indian roasted - than have learned the whole of arguments about bearing pain" (see above).

We can therefore observe that Christians aimed to depict the martyr as a kind of "hyperthanatic" philosopher whose behavior in the face death showed that it had no power over him. Here, however, the question arises which was already asked by Tertullian:

"All who witness the noble patience of its martyrs, as struck with misgivings, are inflamed with desire to examine what is the cause (quid sit in causa)?"41

${ }^{35}$ After S. Benko, Pagan Rome and the Early Christianity, Bloomington 1984, 41.

${ }^{36}$ Epictetus, Diatribae 4, 7, 6, ed. H. Schenkl: Epicteti dissertationes ab Arriano digestae, Stuttgart 1965, 417, transl. T.W. Higgison: The Works of Epictetus, vol. 2, Boston 1891, 176.

${ }^{37}$ Dodds, Pagan and Christian, p. 132.

${ }^{38}$ Martyrium Pionii 17, 2, ed. A. Hilhorst: Martyrium Pionii, in: Atti e Passioni dei Martiri, p. 182, transl. É. Rebillard, Greek and Latin Narratives, p. 73. Cf. F. Avemarie - J.W. van Henten, Martyrdom and Noble Death. Selected Texts from Graeco-Roman Jewish and Christian Antiquity, London - New York 2002, 14: "Jewish and Christian martyrs also shared Socrates' attitude toward death, which was ideal in the eyes of many in the imperial age."

${ }^{39}$ Martyrium Polycarpi 13, 3, ed. Dehandschutter, p. 17, transl. Rebillard, p. 99.

${ }^{40}$ Cf. J.M. Kozłowski, Polycarp as a Christian Gymnosophist, StPatr 51 (2011) 15-24.

${ }^{41}$ Tertullianus, Ad Scapulam 5, 4, ed. E. Dekkers, CCL 2, Turnhout 1954, 1132, transl. P. Holmes, ANF 3, Grand Rapids 1980, 108. 
4. The martyr as mystes. When trying to answer Tertullian's question one can quote Marcus Aurelius' opinion that the Christians' readiness to face death

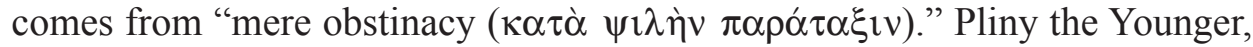
the governor of Bithynia, wrote to the Emperor Trajan that the interrogated Christians were characterized by "pertinacia" and "inflexibilis obstinatio." 42 Tertullian reports that Arrius Antoninus, the governor of Asia, when confronted with the Christians' obstinacy and willingness to die, resignedly said: "O miserable men, if you wish to die, you have precipices or halters." ${ }^{43}$ This, however, is the point of view of the Roman magistrates. For those whose task was to ensure Roman governance, the Christians' behavior seemed irrational stubbornness and nothing more. ${ }^{44} \mathrm{~A}$ different answer to the question about the martyrs' source of power is consistently given by Christians themselves. In contrast to the philosophers, martyrs resist suffering not thanks to the power of the mind or any other natural force, but thanks to the power of God. It is Christ, present within them and united with them, who endows them with resistance to suffering and courage in the face of imminent death. Minucius Felix puts into the mouth of his porte-parole Octavius the words:

"Boys and young women among us treat with contempt crosses and tortures, wild beasts, and all the bugbears of punishments, with the inspired patience of suffering (inspirata patientia doloris). ${ }^{35}$

The ablativus inspirata patientia doloris points to an external, divine source of power. In Martyrium Lugdunensium we read of a martyr named Sanctus that, "suffering in him, Christ accomplished great glory." 46 According to Tertullian: "Christus in martyre est." ${ }^{\text {" }}$ Cyprian writes that it is Christ, present in the martyr, who triumphs over death: "qui pro nobis mortem semel vicit semper vincit in nobis." 48 Similar examples can be quoted ad libitum. For the Christians, therefore, there is no doubt that it is the union of the martyr with the dying and resurrecting Saviour that is the source of the martyrs' power.

Similarities and analogies between Christianity and the mystery cults were noted long ago. There is ongoing discussion among scholars as to the nature of the relationship between them. ${ }^{49}$ One thing is certain - in the spiritual landscape of the Graeco-Roman world the Christian answer to the spir-

${ }^{42}$ Gaius Plinius Caecilius Secundus, Epistulae 10, 96, ed. B. Radice: Pliny, Letters, vol. 2: Books 8-10. Panegyricus, LCL, Cambridge (Mass.) - London 1992, 286.

${ }^{43}$ Tertullianus, Ad Scapulam 5, 1, CCL 2, 1131-1132, ANF 3, 107.

${ }^{44}$ It is worth noting the study of M.A. Tilley, The Ascetic Body and the (Un)Making of the World of the Martyr, "Journal of the American Academy of Religion" 59 (1991) 467-479, where it is argued that the cause of the martyrs' resistance was, above all, ascetic exercises.

${ }^{45}$ Minucius Felix, Octavius 37, ed. Kytzler, p. 200, ANF 4, 196.

${ }^{46}$ Martyrium Lugdunensium 1, 23, ed. Orbán, p. 70, transl. Rebillard, p. 157.

${ }^{47}$ Tertullianus, De pudicitia 22, 6, ed. E. Dekkers, CCL 2, 1329.

${ }^{48}$ Cyprianus, Epistulae 10, 3, ed. Diercks, CCL 3b, Turnhout 1994, 50.

${ }^{49}$ The present status quaestionis is sketched by Bremmer (Initiation into the Mysteries, p. 142-165). 
itual needs of man largely coincided with that given by the mystery cults. Like them, Christianity proposed intimate contact with divinity and, just as in many of the mystery cults, the salvific experience consisted of participating in the death and resurrection of the divine saviour. ${ }^{50}$ Moreover, Christianity required from its adherents a ritual bath (baptism) and participation in the common meal (Eucharist), elements of which find their close analogies in the mystery cults (see below). Taking this into account, we can safely conclude that when they commonly called their rites "mysteries," 51 the Christians, at least to some extent, were referring to the original meaning of this term. In this light the Christian martyr perfectly embodied the most important postulate of the mystery cults - that of an intimate, salvific relationship with the dying and resurrecting deity.

One aspect of the image of the martyr is especially worth noting - in almost all of the mystery cults known to us, different forms of purification, of sprinkling or washing with water, played an important role. ${ }^{52}$ Jan Bremmer writes about "the omnipresence of baths in Mysteries." ${ }^{53}$ This feature of the mystery cults reminds us, for obvious reasons, of Christian baptism: "This is not to deny that there are some features in early Christian baptism that irresistibly remind one of pagan mystery initiations." ${ }^{54}$ A martyr's death was interpreted in baptismal categories by the ancient Christians. In Martyrium Poly-

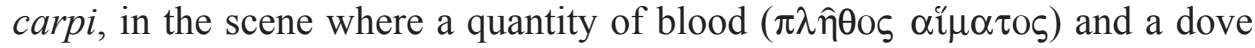
come out $(\pi \varepsilon \rho \imath \sigma \tau \varepsilon \rho \alpha)^{55}$ of Polycarp's pierced side, we are probably dealing with a baptismal image. ${ }^{56}$ In Passio Perpetuae, the pagan mob, seeing the martyr Saturus covered with blood, roars: "Salvum lotum! Salvum lotum! (Well washed! Well washed!)," in which the author of the passio sees a paradoxical testimony of the martyr's second baptism (secundi baptismatis testimonium), and adds a commentary: "For truly one was saved who had bathed in such manner." ${ }^{57}$ Also Tertullian calls martyrdom another baptism: "martyrium aliud

${ }^{50}$ E.g. Col 2:12, ed. E. Nestle - K. Aland, Novum Testamentum Graece et Latine, Stuttgart 199927, transl. New Revised Standard Version, Peabody (Mass.) 2011, 156: "When you were buried with him in baptism, you were also raised with him through faith in the power of God, who raised him from the dead."

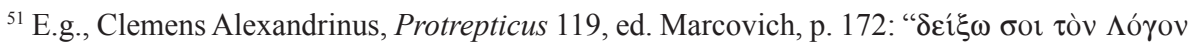

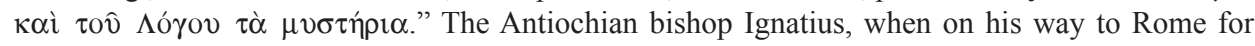
a martyr's death, calls Christians "П Camelot, SCh 10, Paris 1951, 80).

${ }^{52}$ Cf. Burkert, Ancient Mystery Cults, p. 101.

${ }^{53}$ Bremmer, Initiation into the Mysteries, p. 104.

${ }^{54}$ Burkert, Ancient Mystery Cults, p. 102.

${ }^{55}$ Martyrium Polycarpi 16, 1, ed. Dehandschutter, p. 19, transl. Rebillard, p. 101.

${ }^{56}$ Cf. ibidem. See J.M. Kozłowski, Ptonat ogniem, a nie spalat się... Analiza i interpretacja Martyrium Polycarpi 15,2, Warszawa 2014, 138-140.

${ }^{57}$ Passio Perpetuae 21, 2-3, ed. and transl. T.J. Heffernan: The Passion of Perpetua et Felicity, Oxford 2012, 123 and 134. 
erit baptisma. ${ } 58$ We can therefore see that the interpretation of martyrdom in baptismal categories could also evoke pagan mystery ablutions.

We know that ritual meals were an important element of the mystery cults ${ }^{59}$ which could easily evoke the Christian Eucharist. This similarity was so far-reaching that in the middle of the second century, when talking about the implementation of the Eucharist by Jesus, Justin says: “...which the wicked devils have imitated in the mysteries of Mithras, commanding the same thing to be done. For, that bread and a cup of water are placed with certain incantations in the mystic rites of one who is being initiated, you either know or can learn. ${ }^{\circ 60}$ What is significant is that the ancient Christians also interpreted martyrdom in terms of the Eucharist. According to Polycarp, his martyrdom is

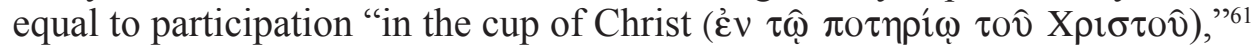
while Polycarp's burning body appears to the Smyrnean Christians as "bread

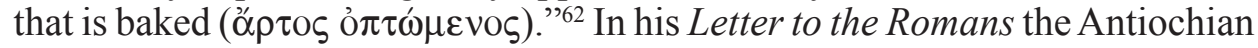
bishop Ignatius, preparing himself mentally for a martyr's death, writes to the

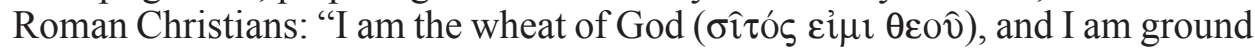
by the teeth of wild beasts that I may be found pure bread of Christ ( $\kappa \alpha \theta \alpha \rho$ ò

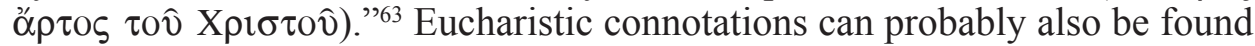
in a scene from Acta Carpi, in which the otherwise unknown Agathonike, wanting to join Carpus burning the stake, cries out: "This meal ( $\tau$ ò ópı $\sigma \tau$ ov $\tau$ ๆ $\tau_{0}$ ) has been prepared for me, so I must partake and eat the glorious meal

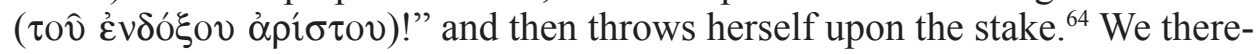
fore observe that Christian martyrdom was interpreted in sacramental terms, which is reminiscent of some of the constitutive elements of the mystery cults.

In the figure of the martyr one can observe the effective realization of two soteriological ideals which appeared in Graeco-Roman culture in response to the drama of human mortality. On the one hand, the martyr fulfills the ideal of the mystes, who is perfectly united with God and filled with the hope of immortality, and, on the other hand, through his steadfast attitude toward suffer-

${ }^{58}$ Tertullianus, De pudicitia 22, 9, CCL 2, 1329.

${ }^{59}$ Cf. Burkert, Ancient Mystery Cults, p. 110.

${ }^{60}$ Iustinus Martyr, Apologia prima 66, 3-4, ed. A. Wartelle, in: Saint Justin, Apologies, p. 190, transl. A. Roberts - J. Donaldson, ANF 1, 185.

${ }^{61}$ Martyrium Polycarpi 14, 2, ed. Dehandschutter, p. 18, transl. Rebillard, p. 101.

${ }^{62}$ Ibidem 15, 2, ed. Dehandschutter, p. 19, transl. Rebillard, p. 101. Eucharist connotations are evident in both images (see first of all Kozłowski, Płonat ogniem, p. 112-113).

${ }^{63}$ Ignatius Antiochenus, Epistula ad Romanos 4, 1-2, éd. P.T. Camelot, SCh 10, 130, transl. W. Schoedel: Ignatius of Antioch: a Commentary on the Letters of Ignatius of Antioch, Hermeneia, Philadelphia 1985, 181.

${ }^{64}$ Acta Carpi 42, ed. H. Delehaye, Les Actes des martyrs de Pergame, AnBol 58 (1940) 157, transl. É. Rebillard, in: Greek and Latin Narratives, p. 43-45. 
ing and death the martyr fulfills the ideal of mors philosophi. The novelty was that Christianity combined these two ideals into a harmonious unity. Moreover, Christianity managed to create, in a mysterious way, an exclusive ideal of mors philosophi that was accessible to (using Plato's expression) oi $\pi 0 \lambda \lambda$ oí. In the article Martyrdom as a Paradoxical Testimony of Life in the Acts of the

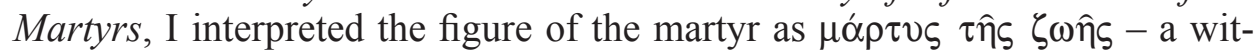
ness of life. ${ }^{65}$ This term had, above all, a theological meaning. In light of the

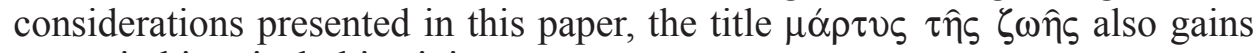
a certain historical objectivity.

\section{(Summary)}

The creation of the concept of the martyr by ancient Christianity was undoubtedly one of the reasons why this young religion could endure through times of persecution and also attract new believers. But what exactly made this concept so effective? Among the many mutually non-exclusive answers, one more may be provided: the person of the martyr simultaneously fulfilled, on a previously unknown level of intensity and scale, two soteriological ideals of the ancient world, i.e., that of the dying philosopher whose attitude toward death showed that death had no power over him and that of the mystes intimately united with the dying and resurrecting divinity.

\section{MĘCZENNIK JAKO HIPERTANATYCZNY FILOZOF I MISTA, A ZWYCIĘSTWO CHRZEŚCIJANSTWA}

\section{(Streszczenie)}

Stworzenie przez starożytne chrześcijaństwo postaci świadka-męczennika było niewątpliwie jedną z przyczyn, dla których owa młoda religia przyciagała do siebie nowych wyznawców także w czasie prześladowań. Dlaczego jednak postać męczennika okazała się tak skuteczna? Wśród wielu wzajemnie nie wykluczających się odpowiedzi, można udzielić również następującej. Męczennik jednocześnie urzeczywistniał $\mathrm{w}$ sobie dwa soteriologiczne ideały grecko-rzymskiego świata: ideał umierającego filozofa, którego niezłomna postawa wobec śmierci pokazuje, że nie ma ona nad nim panowania, oraz ideał misty, adepta kultu misteryjnego, który uczestniczy duchowo w śmierci i zmartwychwstaniu czczonego przez siebie bóstwa.

Key words: Christian martyrdom, ancient philosophy, mystery cults, death, life, soteriology.

${ }^{65}$ J.M. Kozłowski, Męczeństwo jako paradoksalne świadectwo życia w Aktach i Pasjach Męczenników, VoxP 27 (2007) t. 49, 318. 
Słowa kluczowe: chrześcijańskie męczeństwo, filozofia starożytna, kulty misteryjne, śmierć, życie, soteriologia.

\section{BIBLIOGRAPHY}

\section{Sources}

Acta Carpi, ed. H. Delehaye, Les Actes des martyrs de Pergame, AnBol 58 (1940) 142176, transl. É. Rebillard, in: Greek and Latin Narratives About the Ancient Martyrs, Oxford 2017, 37-45.

Apuleius, Metamorphoses, ed. R. Helm: Apuleius, Metamorphoseon libri XI, Berlin 2008. Cicero, De legibus, ed. C. Büchner: M. Tulli Ciceronis De Legibus libri tres, Firenze 1973, transl. C.W. Keyes, in: Cicero. De re publica, De legibus, LCL, Cambridge (Mass.) London 1988, 287-519.

Clemens Alexandrinus, Protrepticus, ed. M. Marcovich: Clementis Alexandrini Protrepticus, Supplements to Vigiliae Christianae 34, Leiden - New York - Köln 1995.

Clemens Alexandrinus, Stromata, ed. O. Stählin, GCS 15, Berlin 1985, transl. B.P. Pratten, ANF 2, Grand Rapids 1983, 299-567.

Cyprianus, Epistularium. Epistulae 1-57, ed. Diercks, CCL 3b, Turnhout 1994.

Diogenes Laertius, Vitae philosophorum, ed. T. Dorandi: Diogenes Laertius, Lives of Eminent Philosophers, New York 2013, transl. R.D. Hicks: Diogenes Laertius, Lives of Eminent Philosophers, vol. 1-2, LCL, Cambridge (Mass.) - London 1958.

DiphiLus, Balneum, ed. J.M. Edmonds, in: The Fragments of Attic Comedy, vol. 3a, Leiden 1961, 97-154.

Epictetus, Diatribae, ed. H. Schenkl: Epicteti dissertationes ab Arriano digestae, Stuttgart 1965, transl. T.W. Higgison: The Works of Epictetus, vol. 2, Boston 1891.

Epistula ad Colosenses, ed. E. Nestle - K. Aland, Novum Testamentum Graece et Latine, Stuttgart 199927, 523-531, transl. New Revised Standard Version, Peabody (Mass.) 2011, 155-157.

EurIPIDES, Bacchae, ed. E.R. Dodds: Euripides, Bacchae, Oxford 1960, transl. T.A. Buckley, The Tragedies of Euripides, vol. 1, New York 1877, 249-282.

Gaius Plinius Caecilius Secundus, Epistulae, ed. B. Radice: Pliny, Letters, vol. 2: Books 8-10. Panegyricus, LCL, Cambridge (Mass.) - London 1992.

Hymnus in Cererem, ed. and transl. M.L. West, in: Homeric Hymns, Homeric Apocrypha, Lives of Homer, LCL, Cambridge (Mass) - London 2003, 32-71.

Ignatius Antiochenus, Epistula ad Ephesios, éd. P.T. Camelot, SCh 10, Paris 1951, 66-93, transl. W. Schoedel: Ignatius of Antioch: a Commentary on the Letters of Antioch, Hermeneia, Philadelphia 1985, 33-100.

Ignatius Antiochenus, Epistula ad Romanos, éd. P.T. Camelot, SCh 10, Paris 1951, 124139, transl. W. Schoedel: Ignatius of Antioch: a Commentary on the Letters of Antioch, Hermeneia, Philadelphia 1985, 163-191.

Isocrates, Panegyricus, ed. É. Brémond - G. Mathieu: Isocrate, Discours, vol. 2, Les Belles Lettres, Paris 1956, 15-64.

Iustinus Martyr, Apologia prima, ed. A. Wartelle, in: Saint Justin, Apologies, Études Augustiniennes, Paris 1987, 98-195, transl. A. Roberts - J. Donaldson, ANF 1, Grand Rapids 1981, 163-187.

Iustinus Martyr, Apologia secunda, ed. Wartelle, in: Saint Justin, Apologies, Études Augustiniennes, Paris 1987, 196-219, transl. A. Roberts - J. Donaldson, ANF 1, Grand Rapids 1981, 188-193. 
Lucianus, De morte Peregrini, ed. M.D. Macleod: Luciani opera, vol. 3, Oxford 1974, 188-205, transl. A.M. Harmon: Lucian, vol. 5, LCL, Cambridge (Mass.) - London 1962, 1-51.

Lucianus, Vitarum auctio, ed. M.D. Macleod: Luciani opera, vol. 2, Oxford 1974, 24-50, transl. A.M. Harmon: Lucian, vol. 2, LCL, Cambridge (Mass.) - London 1960, 449-511.

Marcus Aurelius, Meditationes, ed. and transl. A.S.L. Farquharson: The Meditations of the Emperor Marcus Antoninus, Oxford 1944.

Martyrium Lugdunensium, ed. A.P. Orbán: Martyrium Lugdunensium, in: Atti e Passioni dei Martiri, ed. A.A.R. Bastiaensen (et alii), Milano 1987, 59-95, transl. É. Rebillard, in: Greek and Latin Narratives About the Ancient Martyrs, Oxford 2017, 145-173.

Martyrium Pionii, ed. A. Hilhorst: Martyrium Pionii, in: Atti e Passioni dei Martiri, ed. A.A.R. Bastiaensen (et alii), Milano 1987, 149-191, transl. É. Rebillard, in: Greek and Latin Narratives About the Ancient Martyrs, Oxford 2017, 47-79.

Martyrium Polycarpi, ed. B. Dehandschutter, in: Polycarpiana. Studies on Martyrdom and Persecution in Early Christianity. Collected Essays, Bibliotheca Ephemeridum Theologicarum Lovaniensium 205, Leuven 2007, 3-22, transl. É. Rebillard, in: Greek and Latin Narratives About the Ancient Martyrs, Oxford 2017, 89-105.

Martyrium Potamiaenae et Basilidis, ed. H. Musurillo, in: Acts of the Christian Martyrs, Oxford 1972, 132-135.

Minucius Felix, Octavius, ed. B. Kytzler: Octavius, München 1965, transl. R.E. Wallis, ANF 4, Peabody (Mass.) 1995, 167-198.

Passio Perpetuae, ed. and transl. T.J. Heffernan: The Passion of Perpetua et Felicity, Oxford 2012.

Pindarus, Fragmenta, ed. A. Turyn, in: Pindari carmina cum fragmentis, London 1952.

Plato, Phaedo, ed. I. Burnet, in: Platonis opera, vol. 1, Oxford 1967 [no pagination], transl. H.N. Fowler, in: Plato, vol. 1: Eutyphro, Apology, Crito, Phaedo, Phaedrus, LCL, Cambridge (Mass.) - London 2005, 193-403.

Plutarchus, Alexander, ed. C. Lindskog - K. Ziegler: Plutarchi vitae parallelae, vol. 2.2), Leipzig 1968, 152-253, transl. B. Perrin: Plutarch's Lives, vol. 7, LCL, Cambridge (Mass.) - London 1967, 223-439.

SophocLes, Fragmenta, ed. S. Radt, in: Tragicorum Graecorum fragmenta, vol. 4, Göttingen 1977.

Tertullianus, Ad Scapulam, ed. E. Dekkers, CCL 2, Turnhout 1954, 1125-1132, transl. P. Holmes, ANF 3, Grand Rapids 1980, 105-108.

Tertullianus, Apologeticum, ed. E. Dekkers, CCL 1, Turnhout 1954, 77-171.

Tertullianus, De pudicitia, ed. E. Dekkers, CCL 2, Turnhout 1954, 1279-1330.

\section{Literature}

Alvar J., Romanising Oriental Gods. Myth, Salvation and Ethics in the Cults of Cybele, Isis and Mithras, Religions in the Graeco-Roman World 165, Leiden - Boston 2008.

Avemarie F. -Henten J.W. van, Martyrdom and Noble Death. Selected Texts from GraecoRoman Jewish and Christian Antiquity, London - New York 2002.

Benko S., Pagan Rome and the Early Christianity, Bloomington 1984.

Bremmer J., Initiation into the Mysteries of the Ancient World, Münchner Vorlesungen zu antiken Welten 1, Berlin - Boston 2014.

Burkert W., Ancient Mystery Cults, Cambridge (Mass.) - London 1987.

Dodds E.R., Pagan and Christian in an Age of Anxiety, Cambridge 1965.

Fox R.L., Pagans and Christians in the Mediterranean World from the Second Century AD to the Conversion of Constantine, San Francisco 1986. 
Greek Mysteries. The Archaeology and Ritual of Ancient Greek Secret Cults, ed. M.B. Cosmopoulos, London - New York 2003.

KarŁowicz D., The Archparadox of Death: Martyrdom As a Philosophical Category, Frankfurt am Main 2016.

KozŁowski J.M., Męczeństwo jako paradoksalne świadectwo życia w Aktach i Pasjach Męczenników, VoxP 27 (2007) t. 49, 307-318.

KozŁowski J.M., Płonat ogniem, a nie spalat się... Analiza i interpretacja Martyrium Polycarpi 15,2, Warszawa 2014.

KozŁowski J.M., Polycarp as a Christian Gymnosophist, StPatr 51 (2011) 15-24.

Reale G., Storia della Filosofia Antica, vol. 3, Milano 1987.

ReITZENSTEIN R., Die hellenistichen Mysterienreligionen nach ihren Grundgedanken und Wirkungen, Leipzig $1972^{3}$.

STARK R., Reconstructing the rise of Christianity: The Role of Women, "Sociology of Religion" 56 (1995) 229-244.

Stark R., The Rise of Christianity. A Sociologist Reconsiders History, Princeton 1996.

Sterling G., Mors philosophi: The Death of Jesus in Luke, HTR 94 (2001) 383-402.

Tilley M.A., The Ascetic Body and the (Un)Making of the World of the Martyr, "Journal of the American Academy of Religion" 59 (1991) 467-479. 
